\title{
Chemistry of the Tanning Process
}

$\mathrm{T}$ HE advance which has been made in recent times in the understanding of the chemical reactions which underlie the ancient craft of tanning was well illustrated by the papers given in the discussion held on September 12 in Section B (Chomistry) of the British Association meeting at Leicester.

In the opening paper, Dr. D. Jordan Lloyd pointed out that in using hidos and skins as raw materials, the tanner has a material which by its biological structure possesses firmness and flexibility and is highly suited for a large number of social purposes, yet, owing to the chemical activity of the protein which forms the fibres and the large amount of water held in the skin, possosses a chemical instability towards its environment and a liability towards bacterial attack that makes it unsuitable for use in its natural condition. The problem confronting the tanner, thereforo, is how to preserve the desirable mechanical features due to the micro-structure while removing undesirable ehemical properties.

The protein of the skin fibres, namely collagen, consists of elongated molecules lying parallel to each other to form micro-crystals, and these are grouped togethor to form long fibrils which are drawn together into fibres and fibre-bundles. The protein molecules have their centres of hydration and of chemical activity on their side chains, which project from the main elongated backbone of the molecule. By the process of vegetablo tanning, the active centres of the side chains of the collagen molecules react with active centres in the tannin molecules, and since the latter are colloidal, it is necessary before tanning to give the skins a pretreatment which will open up channels in the structure sufficiently to allow the large colloidal molecules to pass in, not only between the fibres and fibrils but also between the individual molecules. Dilute alkalis have this action and suspensions of limo in water are usually used for this purpose. The interaction of tannin and collagen leads to the suppression of chemically active centres, to the elimination of water and to the protection of the polypeptide link in the collagen molecules.

The chomistry of the tannins themselves was dealt with by Prof. K. Froudenberg. The characteristic feature of a tannin molecule is that it is a large molecule with a high content of phenolic groups. The gallotannins aro esters of glucose and gallic acid or glucose and ellagic acid, while the catechol tannins are polymerised catechins. The reaction between protein and tannin occurs between the amine and amide groups of the former and the phenolic groups of the latter. This reaction is also found between tannins and amines and amides of low molecular weight, but the more complicated the amides, the further the reaction proceeds. The reaction of tanning also involves a subsequent oxidation of the collagen-tannin compound. All tannins contain a hydrophobic nucleus surrounded by hydrophilic groups. Dr. P. Maitland gave a detailed account of the preparation and properties of the tannin from quebracho wood.

The fact that the peptido link of the protein molecules is involved in the tanning process was again emphasised in a paper by Prof. Max Bergmann. Proteolytic enzymes attack gelatin at a free surface, but only attack the chemically similar collagen of raw hides and skins at surfaces where the fibres have been cut across. After the liming treatment, however, trypsin is able to attack the fibres along their length as well as at their ends. The effoet of tanning is to increase the resistance of the limed fibres to attack by trypsin. In vegetable tanning, however, the liability to digestion by trypsin is never completely lost in tanned hides, though the extent to which the tanned fibre may be attacked is influenced by the pretanning treatment and by the nature of the tanning materials used in the tannage; even the size of the tannin molecule may have an important effect on the resistance of the leather to digestion. The protection of the peptide link by the tanning reaction is, however, a very definite fact.

Mr. F. C. Thompson rather emphasised the importance of the reaction between tannins and the amino groups of the protein. Tannins are themselves acid bodies ionising in aqueous solution, and the amino groups of the collagen exist as basic centres carrying positive charges. The first reaction that occurs on mixing tannin and protein is, therefore, salt formation, and since tanning always takes place in acid solutions, there is elimination of froe acid. Tannins can displace strong acids, such as hydrochloric acid, from combination with gelatin, and $\mathrm{Mr}$. Thompson suggested that the formation of an insoluble salt between tannin and protein would be sufficient to account for this fact.

Dr. F. E. Humphreys brought the discussion back to tho question of the importance of the molecular weight and the degree of hydration of the constituents of the more common vegetable tanning materials and showed that in general, high average molecular weight, as determined by depression of the freezing point, is associated with low average degree of hydration, as determined by the Gortner sugar method. These factors of molecular size and hydration are probably the basis of the property of tan liquors usually deseribed by tanners as 'astringency'.

Dr. H. Phillips again emphasised tho importance of the size and degree of hydration of the tannin molecules and pointed out that although interaction between golatin in solution and tannins may be rapid, that betweon hide and skin and tannins is slow sinco the colloidal tannins have to penetrate the structure of the hide. The rate of this penetration depends on the size of the inter-molecular spaces in the hide, the size of the tannin molocules, the intensity of the electrical charge on the molecules of both protein and tannin and the degree of hydration of the tannin molecules. Hides and skins immersed in a simple solution of a tannin would only tan on their outer surfaces, which would become blocked with tan. The chemical properties of the tannins set limits to the extent to which the tanner can assist diffusion by widening tho inter-molecular spaces in the hide through adjustment of the acidity of the liquors. For this reason the presence of substances, classed together as non-tannins, is important, as these substances, which are generally heavily hydratod, combino with tannins, producing complexes which are more hydrated than the original tannins. Because these complexes are more hydrated, they do not form water-resistant linkages with the collagen and can therefore penetrate right into the hide. 'Tho astringency of any tanning material is thus inversely proportional to its degroe of hydration. Dr. Phillips showed how tannins and collagen both holding water 
at their polar groups can come together and form hydrophobic compounds.

The interesting feature of this series of papers was the growing roalisation on the part of chemists of the importance of structure, be it molecular, micollar or microscopic. Certainly the chemistry of the tanning process cannot bo explained without taking structure into account. With the small molecules which usually enter into the better-known reactions of classical organic chemistry, the significance of their stereomotric pattorn is not very conspicuous, but as soon as large colloidal molecules, such as tannins and proteins, have to be considerod, all grades of structure play an important part in controlling the coming together of the active centres of the two interacting components. The great importance of water as playing an active rôle in the chomical processes was also evidently in the minds of most of the speakers. The chemistry of tanning is the chemistry of turning the hydrated and putrescible material, collagen, into the dehydrated material, collagen tannate, with its active centres suppressed and the peptide links protected from the liability of putrefactive attack.
D. J. L.

\section{Eighth General Conference of Weights and Measures}

$\mathrm{U}^{2}$ NDER the treaty known as the 'Convention du Mètro', made in 1875 and revised in 1921, 48 delegatos, representing 29 out of the 31 nations now adhering to the Convention, assembled in the historic Salon de l'Horloge, at tho Ministèro des Affaires Etrangères in Paris on October 3, under the presidency of the French Minister of Industry and Commerce, M. Serre, for the opening session of the eighth Conférence Générale des Poids et Mesures.

At the subsequent meotings of the Conference, held at the Bureau International des Poids ot Mesures, Sèvres, under the presidency of M. Cotton, membor of the Institut de France, a varied programme of considerable importance to all concerned with precise measurement, whether from an industrial or scientific point of view, was transacted.

After receiving the report of the International Committeo on the work of the Buroau for the six years which have elapsed since the meetings of the provious Conféronce Générale, the Conference first authorised the issue of now certificatos for those of the national copies of the metre and the kilogramme which had been found, on re-verification, to have varied by more than tho amounts regarded as possibly attributable to experimental error. Incidentally, the rocent researches of the Bureau have led to the conclusion that the differences botween the coefficients of thermal expansion previously attributed to the various national copies of the metre were probably not real, and that it would bo better to assumo a uniform mean value of the coefficient for all bars constructed from the same melt of the 10 per cent iridio-platinum alloy of which they are made. The Conforence theroforo also sanctioned tho issue of amonding certificates giving effect to this change, which, since the bars originally were not actually compared at $0^{\circ} \mathrm{C}$., leads also to certain small changes in their accepted values at this temperature.

The Conference was informed of the results of recent determinations of the length of the metro in terms of the wave-length of the red radiation of cadmium, both at the National Physical Iaboratory in Great Britain, and at the Physikalisch-Technische Reichsanstalt in Germany, and referrod to the International Committee for further study a proposal to adopt a wave-length of visible light as the basis for the future definition of the unit of length.

At the previous Conference a new series of specifications for the international (thermodynamic) scale of temperature was given provisional sanction, and has since been in general use by the principal national laboratories of the world. A number of errata in the text of these specifications were corrected by the recont Conference, which also arranged for the calling of a Special Thermometric Conference to be held under its auspices, at which the details of the specifications could be further considered with the view of their final ratification and adoption at the next general Conference to be held in 1939.

On the proposition of the Intornational Committee, based on the recommendation of its special Consultative Committee for Electricity, the Conference took the important step of adopting, in principle, the eventual substitution of the 'absolute' c.G.S. system of electrical units for the present International System, leaving to the Committee the duty of fixing, in collaboration with the various national laboratorios, the relationships between the old and now units, and the date when the change should become effective. As regards the volt and ampere, the changes involved are not large enough to be of commercial significance at the present time, and it is well that the change should be mado before increased precision in everyday measuroment makes theso significant. As regards the ohm, the change in this unit amounts to a decrease of about 5 parts in 10,000 , which is, of course, approciable in relation to the possible accuracy of comparison of resistance coils, and will therefore need to be taken into account by the makers and users of such instruments.

The Conforence adopted a resolution putting on record that it regards itself, by virtue of the 1921 revision of the Convention, as the natural successor to the London Conference of 1908 which fixed the present electrical units, and in consequence as having the necessary powers to amend the decisions of that Conference if and when this may be thought necessary.

Following another recommondation of the Consultative Committeo for Electricity, the Conference authorised the International Committee to constitute a separate Consultative Committee on similar lines to deal with the subject of photometric standards. In the constitution of this new Committee care is to bo taken to secure as close liaison as practicable with the Select Committoo of the International Illumination Commission, and its functions will be strictly limited, at least for the present, to the coordination of the work of the various national laboratories. 'The adoption of a black body, at tho melting point of platinum, as the ultimate standard of luminosity, is envisaged, but all technical details were left, in the first instance, for consideration by the Committee.

A proposal by tho delegate of the U.S.S.R. to establish yet another Consultativo Committee, to deal with questions of practical metrology, that is, everyday control of weights and measures for commorcial purposes, was referred back to the Intornational Committee for consideration. J. E. S. 